\title{
Three perspectives on the Sabbath
}

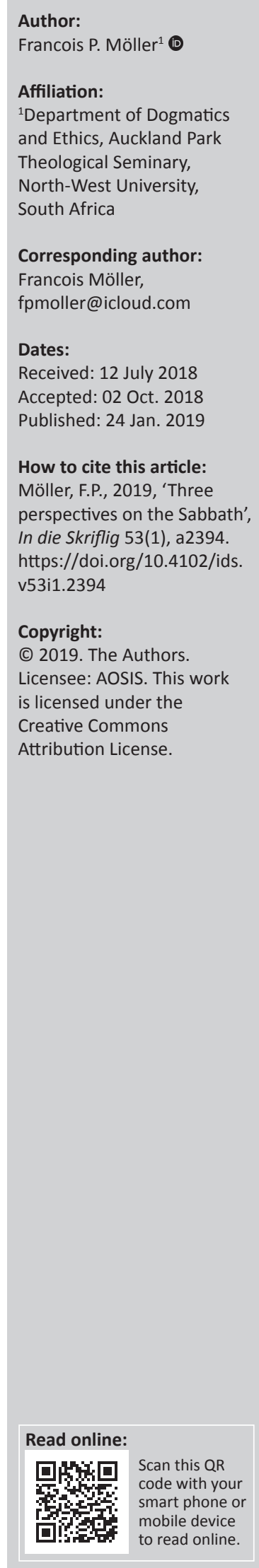

There is still confusion in theology and especially among members of the church concerning the fourth commandment and its observance. The following questions could be asked: What is the meaning of the Sabbath? What is the intention of rest on this day? Ought this commandment still be honoured like the other nine commandments of the Law? Does it still have any meaning for the church, or is Sunday a replacement for the Sabbath? The objective is to obtain greater clarity concerning the meaning, contents and application of the Sabbath as presented in both the Old and the New Testament. This is done from a dogmatic emphasis by dividing the Sabbath into three perspectives: The Creation Sabbath (God's identification with it), the Covenant Sabbath (Israel's identification with it), and the Atonement Sabbath (the church's identification with it). This division does not assume three separate Sabbaths, but they are perspectives on the one Sabbath of God. The threefold perspective will contribute to a universal view on the Sabbath as presented in the creation narrative, the nation of Israel, and the church of the New Testament. This universal view is grounded in Christ who is the focal point, contents and connection between the three given perspectives. It is a Christocentric point of view that gives perception on the meaning, observance, application and message of the Sabbath for the church and every believer of our day.

\section{Introduction}

In Christian traditions, and especially that of the western church, creation is generally presented as only the six days' work, while the completion of creation on the seventh day is much neglected, or even overlooked altogether (Moltmann 1985:276). This article is an attempt to get more clarity from a dogmatic perspective on the Sabbath as presented in the creation narrative, the life of Israel, and the church of the New Testament.

In dealing with this threefold view, the Sabbath is divided into three categories:

- The Creation Sabbath (Creator - Creation narrative).

- The Covenant Sabbath (Israel - Old Testament).

- The Atonement Sabbath (Church - New Testament).

The intention is not to differentiate between three independent and autonomous Sabbaths, but to appreciate the one Sabbath of God from these three perspectives or accentuations. ${ }^{1}$

\section{The Creation Sabbath}

The Creation Sabbath has a specific reference to God as Creator. He has rested on this day, and he blessed it and made it holy:

Thus, the heavens and earth were completed in all their vast array. By the seventh day God had finished the work He had been doing; so on the seventh day He rested from all his work. And God blessed the seventh day and made it holy, because on it He rested from all the work of creating that He had done. (Gn 2:1-3)

\section{God rested}

The reference to God's rest on the seventh day does not mean that he was exhausted or tired. God is not a human being that became weary and fatigued. Even the anthropomorphism in Exodus 31:17, where the Sabbath observance is backed up by the astonishing statement that the Lord paused to 'get His breath back' (ינפש - jinnāphash) on the 7th day, does not refer to God as being exhausted, but rather invigorated. In terms of the Creator God we read in Isaiah 40:28:

Do you not know? Have you not heard? The Lord is the everlasting God, the Creator of the ends of the earth. He will not grow tired or weary, and his understanding no one can fathom.

1.For some other divisions of the Sabbath, cf. the article of Kessler (2012).

2.All biblical quotations are from The Holy Bible - New International Version. 
The Hebrew word 'shabbat' as being used in relationship to God, has a twofold meaning:

- It refers firstly to God seizing or stopping his creation activities. This meaning of the word 'shabbat' is found for example twice in Isaiah 14:4:

How the oppressor has come to an end (shebat)! How his fury has ended (shabetah)!

- Schenck also underscores this meaning of the word 'shabbat':

He did so not because He was physically tired, but because the creation was complete. There was nothing more to add and no need to improve it. God was well pleased with the final product and ceased his activity (1999:71).

- Secondly, the Hebrew word 'shabbat' refers to 'rest' as found in most translations of the creation narrative. Here we have the deeper meaning of 'shabbat' as being used in connection with God. 'Rest' refers here to the 'manner' or 'state' of God's Being, from human perspective (Möller 1997:26). 'Shabbat' presents the eternal rest of God that speaks of perfect love, peace, goodness, holiness and all that could be connected to the marvel of God's existence and his kingdom. Where there is perfect love, peace, goodness, holiness, et cetera - there is also perfect rest.

Lowery (2000) includes also God's perfect or sovereign rule in creation as part of his rest:

Yahweh grants Israel rest from all its enemies at the time of the conquest (Deut 3:20; Josh. 1:13-15; 23:1). Yahweh does the same to David (2 Sam 7:1, 11; contra 1 Kgs. 5:3) and Solomon (1 Kgs 5:4; 8:56; $1 \mathrm{Chr} 22: 9)$. In the larger passage, rest is associated with dynastic election and the building of Yahweh's temple in Jerusalem. David and Solomon are able to consider building Yahweh's house because Yahweh has granted them rest from their enemies round about. Rest is security, political stability, a firm and benevolent grip on power to preserve life-giving order. Rest is 'shalom'. God rests at the end of creation because God is able to rest. God's benevolent rule in the universe is unchallenged. Sabbath rest is a celebration of God's enthronement as universal sovereign. (pp. 88-89)

\section{Temporal-spatial beginning with no ending}

In his creating actions, the eternal God made the heavens and earth in a time span of six days. The seventh day, however, stands in contrast to the other six creation days in the sense that these six days are presented as demarcated periods with a specific evening and morning. The 7th day has a temporalspatial beginning, but no ending as Lowery (2000) summarises:

The seventh day account does not end with the expected formula 'there was evening and morning'. Breaking the pattern in this way emphasizes the uniqueness of the seventh day and opens the door to an eschatological interpretation. Literarily, the sun has not yet set on God's Sabbath. (p. 90)

In other words, the first day and the other creation days describe the way in which the eternal God created the heavens and the earth with time. The seventh day has a beginning in time, but also an 'openness' (without an end) taken up into eternity. In this sense it speaks of the connection between God and creation. In terms of this connection, Moltmann (1985:276) refers to the Sabbath as the presence of eternity in time, and in agreement with Lowery (2000:90), a foretaste of the world to come.

\section{Day seven}

The number 'seven' indicates in a specific context, also something of the connection between God and creation. For example, in the context of Christ's genealogy, as found in Luke 3:23-38 the number 'seven' plays an important role. Groenewald (1973) explains:

Waarom die getal 7 so prominent is, hang waarskynlik saam met die rol wat hierdie getal in die apokaliptiek speel, soos ook blyk uit die Openbaring van Johannes. Die getal het simboliese betekenis. Die mees bevredigende verklaring is dat 7 gelyk is aan 3 plus 4, d.w.s. die getal van die Goddelike Drie-eenheid en die getal van die vier windstreke, d.i. die hele aarde of mensheid. Saam dui 3 plus 4 dus op die bemoeiing van God met die mensheid [Why the number 7 is so prominent, corresponds most likely with the role it plays in the apocalyptic material, as also seen in the Revelation of John. This number has symbolic meaning. The most acceptable explanation is that 7 equals 3 plus 4 , in other words the number of the Trinity and the number of the four points of the compass the whole earth or mankind. Thus, 3 plus 4 refers to God's intervention in his relationship with humanity]. (p. 51, [author's own translation])

By this remark Groenewald does not imply that the doctrine of the Trinity was clearly understood in the Old Testament or even by Luke in writing Christ's genealogy with its prominence on the number 7 . Reference is made to its use specifically in the apocalyptic material of John that consists inter alia of several numbers used in a symbolic manner. The point is that even in apocalyptic material the number 7 indicated the strong connection between God and creation.

The importance of the number 'seven' should of course and firstly, be seen in terms of the seventh day and the fact that God blesses this day and declares it holy. It is since then that the number 'seven' has played an important role in the Bible as seen in many instances and situations. The importance of this number as far as the Sabbath is concerned, is that it also communicates something of the connection between God and creation, and therefore also something of creation's purpose. Creation should have been realised from the eternal God, but eventually debouch again from time into God's eternity and his kingdom, so that God may be glorified and be all in all (1 Cor 15:28). Paul wrote in Romans 11:36:

For from Him and through Him and to Him are all things. To Him be the glory for ever! Amen.

\section{The glory of God}

The six days and the Sabbath's connection with eternity designate unmistakably God's glory as the authentic principle of creation, or as Fergusson (2010) puts it:

Recent exegesis has pointed out that the climax of the story is not the creation of human beings on the sixth day, but the day of rest that follows.... On the Sabbath, the world and its Maker rejoice in the harmony of the good creation. Stressing the cosmic 
dimension of the day of rest, recent theology has sought to offset the anthropocentrism that has sometimes characterized earlier theologies of creation. The world is not made only for human benefit but for the glory of God, a glory that is attested also by other forms of life. (p. 73)

In this regard Lowery (2000) has a problem with the division of the biblical chapters of the creation narrative. Verse 31 of chapter 1 marks the end of day six, while the next sentence (2:1) begins a new chapter that includes the Sabbath. He (Lowery 2000) declares that the effect is a devaluation of the Sabbath and an exaltation of humanity:

It implies that the story ends after day six, with humans created male and female in the image of God and authorized to rule the earth and master it. It emphasizes work over rest and encourages an anthropocentric reading of the world that had destructive consequences in modern age. It also runs counter to the narrative of the story. (p. 87)

Fergusson and Lowrey's objections against an anthropocentric reading of the creation narrative are well taken. Creation is not only made for human benefit but for the glory of God. Paul also sees the glory of God as the highest principle in Christian conduct (cf. 1 Cor 10:31). It is not about man, not even what he has achieved, but all about a creation that glorifies God. However, to glorify God brings intimacy between God and creation, especially between God and man. This happens in such a manner that man actual participates in God's glory in the sense that he is invited to rest with God on this day. Barth (1957) expresses this truth as follows:

Die Meinung der biblischen Zeugung ist, ... daß das Geschöpf und vor allem der Mensch an diesem siebenten Schöpfungstag mit Gott geruht habe und als frei, feiernd und freudig bei sich selbst gewesen sei. Obwohl es noch keinerlei Werk hinter sich hatte, in welchem zu wirken es aufhören konnte, obwohl seine Sabbatfreiheit, Sabbatfeier, Sabbatfreude nur auf Gottes und gar nicht auf sein eigenes Werk zurückblicken konnte! Sie konnte nur in der Freiheit, Feier und Freude Gottes begründet sein und sie konnte nur darin bestehen, da $\beta$ das Geschöpf der Einladung Folge leistete, an dieser teilzunehmen (245-246). [The opinion of biblical witnessess is ... that creation (and above all, man), rested with God on the seventh day, and thus was by itself free, happy and joyful. Though there was no work behind man that he could stop doing, and though his Sabbath freedom, happiness and joy was only from God and not at all from his own work to look back onhe could only find freedom, happiness and joy in God, and it could only exist therein that creation followed to share in this invitation]. (pp. 245-246, [author's own translation])

The very fact that God has blessed and sanctified the Sabbath (Gn 2:3), speaks of his complete identification with this day and his handiwork as such. It expresses the intimacy of God to creation as befits also the incarnation of the Word (Cogliati 2010:7). This identification of God with our world, is also expressed by Lowery (2000):

Sabbath, as blessed time, is the cosmic pole around which all other time coheres. Sabbath establishes all of life as a celebration of the worthiness of God and God's created world. Sabbath is a sign of God's benevolent desire for the world. By observing the blessed Sabbath, the world expresses gratitude to the God who calls us into flourishing life. (p. 90)

\section{The Covenant Sabbath}

The Creation Sabbath speaks of God's identification with the seventh day, but the Covenant Sabbath speaks of Israel's identification with this day. We read about this in Exodus 20:8-11:

Remember the Sabbath day by keeping it holy. Six days you should labour and do all your work, but the seventh day is a Sabbath to the Lord your God. On it you shall not do any work, neither you, nor your son or daughter, nor your manservant or maidservant, nor your animals, nor the alien within your gates. For in six days the Lord made the heavens and earth, the sea, and all that is in them, but He rested on the seventh day. Therefore, the Lord blessed the Sabbath day and made it holy.

The importance of this day for Israel is also accentuated in Exodus 31:14-17, where it is called an eternal covenant between God and them:

Observe the Sabbath, because it is holy to you. ... Whoever does any work on the Sabbath day must be put to death. The Israelites are to observe the Sabbath, celebrating it for the generations to come as a lasting covenant (berīt olām). It will be a sign between $\mathrm{Me}$ and the Israelites forever, for in six days the Lord made the heavens and the earth, and on the seventh day He abstained from work and rested. (cf. also Ezk 20:12)

By keeping the Sabbath, the Israelites must actually identify with eternal salvation of peace and rest as God's purpose, not only for mankind, but also for creation (Rm 8:9-23). The fourth commandment should therefore be regarded as much more than just a commandment, it is also something to celebrate. The fact that this day was explained in terms of the rest of God himself, prove that it was regarded as a source of blessing of universal significance, and bears witness to the enthusiasm with which the pious Israelite rejoiced in this day of rest as an act of devotion. It was not until in later Judaism a religion of harsh observances had substituted this blessing to a burdensome duty (Eichrodt 1959:133).

This day of rest for Israel was also seen in a broader context, as the Old Testament also speaks of rest in terms of peaceful living (Dt 28:65); the promised land (Ps 95:11); prosperity (Ps 90:13); joy (Is 14:3). These latter meanings were all flashing demonstrations of the actual and eternal rest that will, in its full consequences break through, in the hereafter.

The Sabbath should have been celebrated by the Israelites as a covenant between them and God. It is a covenant that speaks of the truth that God is a God for them - his part of the agreement, and that Israel should be a people for him - their part of the agreement (cf. Ex 29:45; Lv 26:12; Jr 24:7: 31:33; Ezk 11:20). If they were truly a people for God (serve him whole heartedly and keep his commandments), then they would also 'pass through time into eternity'. In other words, the goal of the Creation Sabbath that connects time with eternity, will then realise for them as well.

The Sabbath as a sign of the covenant between God and Israel, was of course not only a weekly celebration (a covenant feast), but also a seventh yearly celebration as a sabbatical 
rest for the land. The year of jubilee, after seven times seven years, was the year that emphasised particularly God's restorative work not only as Creator but also as Recreator (cf. Lv 25:18), as Carson (1999) puts it:

In this year the sign of the covenant emphasized the covenant God as Redeemer, Liberator, and Saviour, He restores His people and the land on which they live. The land takes an additional rest in this year, and the people who had become servants were liberated. Land that had been sold in payments of debts reverted to its original owner. (p. 31)

This jubilee year highlighted the Sabbath as a sign of the covenant, leading the people to worship the God of the covenant. They worshipped him as Redeemer and Saviour with its full implications found in the New Testament in Christ, who by his redemption and salvation would offer eternal freedom and rest.

For some Rabbis the 7th day even brings some sort of stability and permanence in this world:

The rabbis who recorded the oral tradition of Judaism, considered the Sabbath as the very soul of creation. They believed that the seventh day anchored the earth, and that before the appearance of the seventh day, creation was shaky and unstable. Today many Orthodox Jews assert that the Sabbath gives permanence to an otherwise temporary world. In their minds, insulting the Sabbath causes great injury to everyone and everything. (Schenck 1999:73; A reference to Rabbi Chaim Richman, 1995, The Restoration)

The Rabbis' expression that ... the Sabbath gives permanence to an otherwise temporary world' is in fact another way of expressing how the Sabbath connects eternity (permanence) with time (temporary world). ${ }^{3}$

\section{The Atonement Sabbath}

As already mentioned, the Creation Sabbath speaks of God's identification with the 7th day; the Covenant Sabbath speaks of Israel's identification with this day, but the Atonement Sabbath speaks specifically of the church's identification with this day.

It became clear that the Creation Sabbath pointed to the connection between time and eternity, or creation and God. This connection was violated through sin (Is 59:1), but in Christ restored again:

God reconciled the world to Himself in Christ, not counting men's sin against them. (2 Cor 5:19)

This reconciliation (connection) firstly happened through Christ's incarnation. This was an event by which God in Christ connected himself to a broken and sinful world in a very concrete and tangible way. It was an act of pollution and contamination in the most severe sense of the word.

One should not forget that when Christ became flesh, He never seized being God-Man. He, the eternal God-Man 3.For further reading on the Jewish view of the Sabbath, cf. Heschel (1951). (who is a unity of body, soul and spirit), clothed his glorified body with flesh ('sarks'). ${ }^{4}$ By doing that, a new unity of a body (clothed with flesh), soul and spirit came into being that is actual unthinkable. Christ was as God-Man polluted and tarnished with brokenness, decay and temporality that touched him intensively in body, soul and spirit. No wonder the German philosopher Karl Jaspers (1969:298) said that he is willing to believe in the God of the Old Testament, but not in the God of the Christians, because they have 'dragged God through the dust' by the doctrine of incarnation. To make God flesh in Christ is according to Jaspers impossible and blasphemous.

It is and was also for the Jews unthinkable. The Jews expect a Messiah that will be greater than Moses, more powerful than David, and wiser than Solomon, but He will be a human being, not God-Man. To expect a Messiah that will be God incarnated in the flesh, will according to the Jews be blasphemy. However, by seeing Christ only as an exceptional human being without $\sin$, is a terrible underestimation of the New Testament message of Christ who became flesh. ${ }^{5}$

Christ's incarnation in the flesh, however, included more than God's connection to a broken, sin polluted and degenerating creation. It was also an event that enables him to heal the violated connection between creation and eternity. That is to restore the message of Sabbath. This he has done by taking our penalty of sin (death) upon himself (Rm 6:23). In Hebrews 2:14-15 one reads:

Since the children have flesh and blood, He too shared in their humanity so that by his death He might destroy him who holds the power over death - that is the devil - and free those who all their lives were held in slavery by their fear of death.

\section{Paul wrote in Romans 6:6:}

For we know that our old self was crucified with Him, so that our body of sin might be done away with, so that we would no longer be the slaves to sin.

As his birth in the flesh, so his death on the cross was something unthinkable. Christ who is God, and therefore life (he does not have life; he is life, that is his identity! John 14:6), had died. This happened in his flesh, but touched him in totality because body, soul and spirit represent a unity. The depth of the dimensions this had on Christ as God-Man is far above our comprehension. Paul wrote in terms of atonement:

No eye has seen, no ear has heard, no mind has conceived what God has prepared for those who love Him. (1 Cor 2:9)

In other words, it is too difficult to understand or even think of.

When in Christ, death came in contact to life, death was destroyed, and Christ rose up from the grave as the

4.The writer of this article differs from the pronouncement of the Council of Chalcedon ( $451 \mathrm{AC}$ ) claiming that Christ received his humanity (av $\theta$ pwTOS) from Mary. The (451 AC) claiming that Christ recer conviction is held that Christ is the eternal God-Man who was temporarily clothed

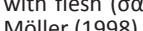

5.For further reading regarding a comparison between the Jewish, Christian and Muslim views on the Sabbath, cf. Ringwald (2007). 
glorified One. What exactly happened, is again above our comprehension, but through this event, the connection between creation and eternity was restored.

Christ's resurrection is something believers already partake in, but it will reach its climax with the day of the Resurrection (at the return of Christ) when our carnal bodies will be replaced with incorruptible and glorified bodies. Paul described it in terms of the metaphor 'swallowed up':

For while we are in this tent, we groan, being burdened, because we do not wish to be unclothed but to be clothed with our heavenly dwelling, so that what is mortal will be swallowed

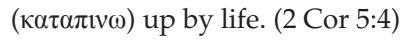

We find the same metaphor also in 1 Corinthians 15:54b:

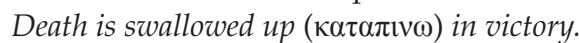

This metaphor of Paul is founded in Christ who is called the firstling or firstfruit ( $\alpha \pi \alpha \rho \chi \eta)$ of those who have fallen asleep (1 Cor 15:20). In line with Paul's metaphor we could say that when Christ rose from the dead, his carnal and corruptible body did not stay in the grave but was 'swallowed up' by life and victory.

Consequently, Christ became the Atonement Sabbath for us who by his incarnation in the flesh, his death and resurrection connected (atoned) fallen mankind again with eternity (God).

\section{Christ is our Sabbath}

We already have mentioned that the seventh day (Sabbath) started within time but flows into eternity. This day speaks therefore of the connection between time and eternity. Christ is the contents and meaning of this connection as expressed in the Sabbath day.

In Christ, as the eternal God-Man, God and mankind are again connected with each other. Only in Christ who became flesh, who died and was resurrected from death, could we again receive eternal life. Only in Christ the Sabbath of God becomes a reality.

Christ is the focal point of, and connection between the three perspectives on Sabbath. As the eternal God-Man and only way to God, he is the Creation Sabbath who connected Adam and Eve before the fall with God. As the promised Messiah, he is the Covenant Sabbath that gave the Old Testament man hope in the realisation of salvation. As God-Man who became flesh, died and being resurrected again, he is the Atonement Sabbath that connects broken, spiritually dead and sinful mankind to eternal life like a branch that is inoculated into the vine (Jn 15:1-6). As the Sabbath of God, he is indeed the Way, the Truth and the Life, and no one can come (connect) to the Father except by him (Jn 14:6).

\section{The Sabbath and the church}

In the New Testament Church were both Jewish and Gentile Christians who accepted Christ as their Savior. Some of these
Jews did not yet understand all the consequences of the relationship between the Old Testament law and the gospel of Jesus Christ. This was also true in terms of separating Israel's Sabbath and Christian Sunday.

Moltmann (1985:293-296) states that this separation has a considerable history that is difficult to reconstruct. For him, this history started after the council of the apostles (Ac 15) that concluded that if Gentiles wished to become Christians, they did not have to become Jews first, and that they were not subject to the law in terms of circumcision or in terms of keeping the Sabbath. This position distinguished Jewish Christians from Gentile ones.

Moltmann continues, that because more and more GentileChristian congregations came into existence, the Christian feast-day (Sunday) parted company from Israel's Sabbath day. This was also a sign of Christianity's abandonment of Judaism and the end of the determining influence of Jewish Christians on the Christian faith. Later, especially after the Constantine period, many popes and theologians justified the feast of Christians on a Sunday by introducing the resurrection of Christ to this day. In fact, the first time in the state legislation of the Christian emperors (3 March 312), may be viewed as the 'birthday' of Sunday as a state day of rest. Moltmann concludes that the Christian feast-day must be regarded as the messianic extension of Israel's Sabbath, and that it will be useful to have Saturday evening devotions that flow into worship on Sunday morning. Maybe Moltmann's idea of Saturday evening devotions is taken from the postSabbath evening prayers as suggested by several Rabbis (Rabbati 1968:477).

It is debatable whether Moltmann's interpretation of history is correct. Paul's letters to the different Christian assemblies, that most likely consisted also of Jewish Christians, do not present different rules in terms of Jewish Christians and Gentile Christians regarding keeping the law and specifically the Sabbath. It is true that different interpretations of the law among members caused problems in the Christian assemblies. This is underscored by Paul's words to the Colossian assembly:

Therefore, do not let anyone judge you by what you eat or drink, or with regard to a religious festival, a new moon celebration or a Sabbath day. These are a shadow of the things that were to come; the reality, however, is found in Christ. (Col 2:16-17)

The contrast set by Paul between 'shadow' $(\sigma \kappa 1 \alpha)$ and 'reality' $(\sigma \omega \mu \alpha)$ is important. It is a contrast set for both Jewish Christians and Gentiles.

Paul did not see a Sabbath that flows or extends into Sunday worship, but interpreted the Sabbath in terms of who Christ is. The Covenant Sabbath is rather seen a shadow of what realised in Christ's act of salvation. A demand to keep the Covenant Sabbath after what Christ has already done, is therefore a demand chasing a shadow, or as Bird (2009) puts it:

The rationale for rejecting the imposition of these Jewish regulations is that they are merely a shadow of what is to come. 
Similar language is used in Heb. 10:1 to describe the Old Testament in relation to Christ. ... The Torah foreshadows and overtures the Messiah who fulfills the precepts of the law. For Greek-speakers shadow also had negative connotations of instability, shiftiness, and emptiness (e.g. 1 Chr 29:15; Jas 1:17; Wis 5:9). That the substance belongs to the Messiah means that the reality posed by the shadow, and the fulfillment of what is to come, belongs to Jesus. (pp. 84-85)

De Lacey (1982:183) is of the conviction that Paul's statement, 'no one is to act as your judge' (Col 2:16), indicates that no stringent regulations are to be laid down, but that festivals like the Sabbath may yet be enjoyed by those who wish to do so.

The Sabbath should rather be regarded as fulfilled in Christ and not something enjoyed by those who wish to do so. Therefore, when the Covenant Sabbath is still celebrated, it boils down to a denial of 'the reality found in Christ' and his fulfilment of the Law (Mt 5:17). Paul wrote to the Galatians:

You who are trying to be justified by law have been alienated from Christ; you have fallen away from grace. (Gl 5:4)

In other words, by keeping the Covenant Sabbath (like circumcision) is a denial of the reality of Christ and what he has already done for mankind.

This is of course contrarily the viewpoint of the Seven-DayAdventists that stated clearly:

The seventh day of the week, commonly called Saturday was sanctified and set apart as the Holy Sabbath, and should, therefore, be observed as the day of worship by all Christian. Gen. 2:1-3; Exod. 16:23, 28; 20:8-11. (Jones 2006:186)

In terms of 'judging', Bird (2009) states:

The underlying assumption is that the Colossians were judged for failing to obey regulations binding upon them, even as Gentiles, if they do not adhere to Jewish practices pertaining to purity laws, Sabbath, and festivals. The implication is that the teachers advocated (partial) adherence to the Torah provides fullness and fulfillment lacking in the Christian message. (p. 84)

Therefore, the Sabbath law's preparatory adumbrating function has come to an end because the messianic reality to which this law pointed, has now arrived.

In referring to the 2nd century fathers (like Ignatius, PseudoBarnabas, Ptolemaeus, Irenaeus and Tertulian), Bauckham (1982) declares that outside the Jewish Christianity, references to the Sabbath commandment support a metaphorical interpretation of the Sabbath, or a rejection of a literal keeping of this day:

Perhaps there were some Gentile Christians who kept the Sabbath but if so, they found no spokesman whose writings survive. The neglect of the Sabbath command in Christian paraenesis goes back to the original conviction of the majority of the Christian missionaries of the early period of the church's Gentile expansion, that the Sabbath was not to be imposed on Gentile converts. The metaphorical interpretation of the commandment was a later development, probably originating in Alexandria, where strong Jewish Christians, like PseudoBarnabas and the redactor of the logion in Gospel of Thomas 27, used to dissuade their 'weaker' brethren (both Jewish and Judaizing Gentile Christians) from Jewish practices. It became popular in the later century, partly in the context of controversy with Judaism, from which the church was increasingly concerned to differentiate itself, but also partly in the context of controversy with Marcion, who repudiated the Old Testament entirely. The attempt to steer a course between Judaism and Marcionite heresy forced Christian writers such as Irenaeus and Tertullian to clarify the elements of continuity and discontinuity between the religion of the Old and New Testaments. The metaphoric interpretation of the Sabbath commandment enabled them to explain how the commandment could be God given and valuable and yet not binding on Christians in its literal sense. (p. 269)

Bauckham (1982) also declares that 2nd century writers were conscious that Sunday is the day of the Lord's resurrection and made this principle the basis of Sunday observance:

For Ignatius, it was Jesus' resurrection from the dead on Sunday that gave Sunday its value as the distinctive mark of Christianity over against Judaism. Pseudo-Barnabas (15:9) and Justin (1 Apol. 67:7) similarly associated the day with the Resurrection, but they are also witnesses to the accumulation of other theological motifs around the practice of Sunday worship. Justin, for example, regarded the first day of the week as the day God began the creation of the world, and he is also the first witness to the Christian symbolic appropriation of the pagan title 'day of the sun' which became common in the Fathers ... In the second century Sunday was also called 'the eight day' a title that lent itself to varied symbolic uses. Because in the Old Testament the eighth day was the day of circumcision, and eight people were saved from the flood, the 'eighth' day could signify the day on which salvation arrived with Christ's resurrection and the day on which baptism was administered. (p. 273)

In other words, there is no 2nd century evidence that Sunday was regarded as a day set apart for rest like the Sabbath. We do not know how much of the day was taken up by Christian corporate activities, but both persecution and economic circumstances must often have kept many Christians at work during the working hours of the day.

However, Christ is the reality of the Sabbath of God, and therefore the 'rest' of this day is specifically connected to him:

Come to Me, all you who are weary and heavy burdened, and I will give you rest. (Mt 11:28)

It is all about an eternal life of rest found in Christ. In Hebrews 4:1; 9-11 we read:

Therefore, since the promise of entering his rest still stands, let us be careful that none of you be found to have fallen short of it. ... There remains, then a Sabbath-rest for the people of God (the church); for anyone who enters God's rest also rests from his own work, just as God did from his. Therefore, let us be diligent to enter that rest, so that no one will fall by following the same example of disobedience (i.e. the unfaithful people of God).

Thus, the believers (the church of the Lord) must be diligent in entering the rest of God. This rest of God refers to eternal life, 
united with him in the hereafter according to the Atonement Sabbath. It is an eternal rest in a new creation of God, as Edwards (2010) explains so clearly:

The risen Christ is the beginning of the new creation, the promised new heavens and new earth (2 Pet 3:13; Rev 21:1-5; 22:13). In this new creation, every creature of earth, sky, and sea will sing praise to the Lamb, who has redeemed the whole creation. $(\operatorname{Rv} 5: 13-14 ;$ p. 147)

The final eternal rest is for the new human being in Christ, delivered from all sin, as well as the mortality of flesh and blood:

I declare to you brothers, that flesh and blood cannot inherit the kingdom of God, nor does the perishable inherit the imperishable. Listen, I tell you a mystery: We will not all sleep, but we will all be changed, in a flash, in the twinkling of an eye, at the last trumpet. For the trumpet will sound, the dead will be raised imperishable, and we will be changed. For this perishable must be clothed with the imperishable, and the mortal with immortality. (1 Cor 15:50-53; cf. Rm 8:18-25)

The demand of the Hebrew writer that believers should be diligent in entering this eternal rest (Heb 4:11), does of course not only refer to the future return of Christ, but also to the present in which we already are able to experience the rest in Christ. Jesus confirmed this on the cross by saying in John 19:30: It is finished ( $\tau \varepsilon \tau \varepsilon \lambda \varepsilon \sigma \tau \alpha 1)$. The words 'it is finished' remind us of God's words after he had finished his creation activities (the Creation Sabbath):

By the seventh day God had finished the work He had been doing. (Gn 2:2)

Christ is not only Creator, but as Savior also Recreator, and as Recreator he called out on the cross the same words: It is finished! Then he went to heaven and sat at the right hand of God the Father (Heb 10:12). In other words, his recreation activities were finished, and therefore we could also now participate in the eternal life of the new creation, although it will only realise in its fullness with the return of Jesus Christ. After all:

... if anyone is in Christ, he is a new creature, the old things passed away; the new has come. (2 Cor 5:17)

\section{The day of the Lord}

Jesus Christ is our Atonement Sabbath who has unified us with the new creation of God. This new creation has broken through with his resurrection on the first day of the week, that also symbolises the first day of the new creation. This day is called in the Bible 'the day of the Lord'. John said in Revelations 1:10:

On the Lord's day I was in the Spirit.

This assumption is, however, questioned since the name

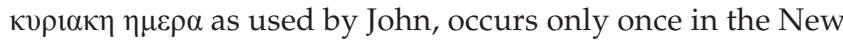
Testament. John is not clear whether he referred to Sunday the resurrection day of Christ. However, in the Didache,

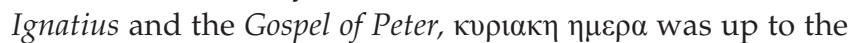
2nd century a technical term rather widespread used at least in Syria and Asia Minor, designating the first day of the week as the Christian day of regular corporate worship (Bauckham 1982:227):

If John was writing in the reign of Domitian, he was writing no more than twenty years before Ignatius' letter to the Magnesians, in the same area. Even if he was writing earlier, it is still extremely improbable that the same title should have been transferred from one religious festival to another. To claim that Revelation 1:10 refers to Easter (or the Sabbath) is mere speculation with no evidence whatever to support it. The whole consistent usage of 2nd-century writers indicates Sunday. ... There is no trace whatever of any controversy as to whether Christians should worship on Sunday, and no record of any Christian group that did not worship on Sunday. This universality is most easily explained if Sunday worship was already the Christian custom, before the Gentile mission and spread throughout the expanding Gentile church with the Gentile mission. (pp. 231-236)

The Didache (80-120 AD; 1965) states:

On the Lord's day of the Lord come together, break bread and

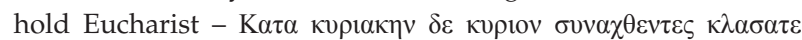

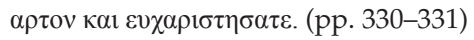

The epistle of Barnabas (70-132 AD; 1965) referres to this day as the eight day:

Wherefore we also celebrate with gladness the eighth day in which Jesus also rose from the dead $-\delta 1 \alpha \kappa \alpha$ $\alpha \gamma o \mu \varepsilon v \tau \eta v \eta \mu \varepsilon \rho \alpha$

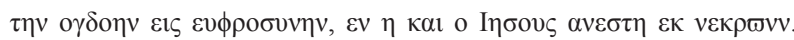
(pp. 396-397)

The conclusion seems that the early missionaries of the Palestine Jewish-Christian churches exported this practice to all GentileChristian churches. The day of the Lord became therefore the day of the church's worship. It was this day that was put aside by believers to celebrate their unification with Christ through his death and resurrection and the accompanied new life. Furthermore, the influence of the pagan 'day of the sun' can be discounted if the origin of Sunday worship is Palestinian.

Thus, it was on this day that:

- Jesus rose from the dead (Mk 16:9).

- Jesus met with his disciples after his resurrection (Mk 16:11-16).

- Jesus appeared to his disciples behind closed doors (Jn 20:19).

- Jesus has sent his disciples as He was sent by the Father (Jn 20:21).

- Jesus blew on his disciples and said: Receive the Holy Spirit (Jn 20:22).

- Jesus appeared to his disciples behind locked doors a second time and spoke to the unbelieving Thomas who then confessed: My Lord and My God (Jn 20:26-28).

- The Holy Spirit was poured out on believers, and the Church was born (Ac 2:1). According to Leviticus 23:16-17 Pentecost was the day after the seventh Sabbath - that was usually a Sunday.

- The Church assembled together (Ac 20:7).

- The offerings were gathered (1 Cor 16:2).

- God started to give his revelations to John on Patmos $(\operatorname{Rv} 1: 10)$. 
The mentioned Scriptures cannot support prove that these narratives presuppose Sunday observance in the churches of their time. However, the fourth Gospel may offer some support for such a claim where it refers to the disciples gathering together on this day (Jn 20:19), but it could not be said with absolute certainty. Maybe when Sunday worship was generally practiced later on, Christians connected these events with the first day of the week as theological support for their observance of this day. It is really impossible to be dogmatic as to the time of the origin of Sunday worship, but as already indicated, it probably began in the early Palestinian church.

McDowell (2013) is convinced that:

... for years the first-century church observed both the Jewish Sabbath and the Lord's Day. They began worshipping together on Sunday primarily because Jesus rose on the first day of the week, and Jesus appeared to his followers more than once on the first day of the week. (p. 78)

However, the day of the Lord, the first day of the week and by implication of a new creation, is not a possibility without Christ who, as our Atonement Sabbath, united the old creation to the new creation. Therefore, we cannot consider Sunday as the Covenant Sabbath in another form. Nor is it a case of Sunday replacing the Covenant Sabbath and that Christians therefore no longer observe the Covenant Sabbath. The Covenant Sabbath is fulfilled in Christ, and therefore we do not observe this day anymore. We do not identify with the promised Messiah (that was for Israel), but with Christ as the fulfilment of the promised Messiah. The resurrection day should rather be regarded as the outcome of the Atonement Sabbath that speaks of God's plan of salvation as realised in Christ, as Edwards (2010) explains:

\begin{abstract}
The resurrection represents something completely unpredictable and new. While many human beings long for life beyond death, and while some faithful Jews had put their hope in general resurrection, the resurrection of the crucified One was beyond all human expectation. It is an unimaginable and amazing act of God in our history. It constitutes a promise that human beings and with them the whole creation will be transfigured in Christ. It contains a claim that the final transformation of all things has already begun in Jesus and is at work in the universe. ... The resurrection is not an intervention of God from without, but the central revelation in our history of the act by which God creates, saves, and brings all to fulfillment. (pp. 93-94)
\end{abstract}

Every believer should therefore celebrate the meaning of this day. Fathers should discipline their families to gather on this day with other believers and worship God for the eternal rest he gave us. It is important that children should see and experience that there are more people serving God than only their family. In fact, the essence of the church is to be a visible testimony and agent of the resurrection at work in the world:

Let us not give up meeting together, as some are in the habit of doing, but encouraging one another, and all the more you see the day drawing near. (Heb 10:25)
Schenk (1999) emphasises '... not give up meeting together' by saying:

Something special happens both to individuals and to a group when people of like minds and hearts gather together. All you have to do is observe a large religious gathering to see evidence of this. A stadium full of thousands of participants praying, singing, and worshipping together generates a level of faith that one person alone cannot possess. The same is true for a small chapel with only a dozen assembled. The fire of faith is fanned when believers come together. (p. 75)

The book of Leviticus calls the Sabbath a day of sacred assembly ( $\mathrm{Lv} 23: 3)$, meaning a time to gather for corporate worship. Jesus endorsed this practice by attending weekly Sabbath services at the synagogue (Lk 4:16). This focus on worship led the Puritans to refer to the Sabbath as 'the market-day of the soul' (Ryken 2003:105). The message is that a special day is needed for corporate devotion to God. It also reminds us of the words of Christ in Matthew 18:20:

For where two or three come together in my name, there I am with them.

The reference in Hebrews 10:25 '... the day drawing near', points to the return of Christ and his judgement. That will be the full breakthrough of the new creation of God, and is often called, like the first day of the week, the day of the Lord (1 Cor 5:5; 1 Th 5:2; 2 Th 2:2; 2 Pt 3:10). That is the day of the completion of God's goal with our creation, and when the Sabbath of God in its full consequences is fulfilled.

\section{Keeping the Sabbath of God}

The command to keep the Sabbath day came after the Fall. The first human couple did not keep the Sabbath, because they were without sin and united with God. God's purpose with creation (as presented by the Creation Sabbath), particularly with man, was not disturbed, and would have debouched into the eternal life with God. Therefore, Adam and Eve already lived in the rest of God by their special unity with Christ. It is a unity that would have reached its climax in eternity.

In fact, from Adam to Joseph, there is no mention of observing the Sabbath until the Israelites are told in the wilderness not to gather the manna on the seventh day (Ex 16:22-26). The manna was to be collected in double portion on the sixth day so that no work for food would have to be done on the Sabbath. It was at receiving the Law in Sinai that the meaning of the Sabbath became clear to Israel. Maybe because Israel was the chosen people to bring forth the Messiah who would have been the fulfilment of the Sabbath.

Sin broke man's unity with God and resulted into a need for a Savior and Redeemer to restore the unity between eternity and creation, and specifically between God and man. The promise to fulfil this need is found directly after the Fall in Genesis 3:15 (Heyns 1978). Here the Lord said regarding Satan:

And I will put enmity between you and the woman, and between your offspring and hers; he will crush your head, and you will strike his heel. (p. 233) 
In keeping the Covenant Sabbath, the Israelites should have identified themselves with the idea that a Messiah will come and unite them again with God and fulfil the promise of Genesis 3:15.

Jesus Christ (the Messiah) came and has restored the unity between God and man. The Covenant Sabbath is therefore fulfilled in Christ by the realisation of the Atonement Sabbath, and with this Sabbath the church identifies itself. The Atonement Sabbath does not refer to a specific day as such (like the Covenant Sabbath), but to the fulfilment of the Covenant Sabbath in Christ. This identification means that we are again united through faith in Christ, and in Christ with the Triune God. Therefore, we have already entered the eternal rest that will break through in its full consequences with the return of Christ. Thus, to keep the Covenant Sabbath as was done in the Old Testament, would boil down to a denial of that what Christ has already done for us in the fulfilment of the Covenant Sabbath. In this sense, we identify also with Adam and Eve before the Fall, who did not live under the obligation of the fourth commandment.

As a sign that we have indeed entered this rest, we celebrate the resurrection day of Christ (Sunday) as the day of the Lord, by corporate worshiping, partaking in the sacraments and preaching.

We also celebrate this day as the first day of the beginning of the week of the new creation in Christ by living every following day of the week an inner life of rest in the Lord. This rest gives us a great gift, especially if in this rest, we respond to the divine invitation to come to him. In him we become our true selves: loved children of God, able to share that love with others, and to realise that we are beloved lovers. Kent (2009) states:

In spiritual rest, we recover our lives, we discover the gift of community with people and with our Creator, and the depth, texture, and richness that gift add to our lives. We get a chance to stop, turn, and really notice the faces of the people running through life beside us and to feel grateful to them. This is no small gift. (p. 31)

The goal is therefore not only to live the values of a resting day once a week, but also to bring them into everyday lives. Each time we live a day specifically dedicated to God and holiness, we have the opportunity in bringing some residual effect into our daily lives. It should be our goal to bring the message of the Atonement Sabbath to the reality of each day (cf. Schlessinger \& Vogel 1998:126).

Although this is a lifestyle that refers in the first instance to our inner life, one cannot neglect the reality of being a body as well. Our bodies need also to come to rest, and the first day of the week ought to be (if possible) a day of bodily rest. While we rest in a way different from the people in the ancient world, we can still learn much from understanding the heart behind God's commandment concerning the Sabbath. We must honour God also by our use of time, in a rhythm of toil and rest, and be reminded that all our time is his gift, to be given back to him and used for him (Packer 2007:67). However, it is not keeping the Sabbath but recognising the wisdom of resting one day of the week.

In other words, the church identifies no longer with the Covenant Sabbath (it is fulfilled in Christ), but with Christ who is the Atonement Sabbath that speaks of a new lifestyle and of rest in God. It is a lifestyle that will find its climax and fullness in eternity as initially expressed by the Creation Sabbath.

\section{Conclusion}

The three perspectives on the Sabbath as presented in the creation narrative (God's identification with the Sabbath), the life of Israel (Israel's identification with the Sabbath), and the church of the New Testament (the church's identification with the Sabbath), helped us to distinguish between the Creation Sabbath, the Covenant Sabbath, and the Atonement Sabbath.

These perspectives and differentiates helped us to appreciate and deepen our understanding of the meaning and goal of the Sabbath as especially reflected in God's goal with creation. It also gave us a universal view on the process of God's actions of restoration in terms of the intention and goal of the Sabbath after being mutilated by the Fall.

The three perspectives also helped us to appreciate Christ as the focal point, contents, and connection between the Creation Sabbath, the Covenant Sabbath and the Atonement Sabbath as actually one Sabbath of God in Christ. With this Christocentric perspective on the Sabbath, it became clear how the church should position itself to the Sabbath, and how it should relate to the Old Testament commandment to keep it. It also encourages the church to embrace God's invitation to rest with and in him, accompanied with faith in the marvel of his existence that speaks of perfect love, truth, righteousness, goodness, holiness, and all that is ascribed to him in his self-revelation to us.

\section{Acknowledgements Competing interests}

The author declares that he has no financial or personal relationship(s) which may have inappropriately influenced him in writing this article.

\section{References}

Barth, K., 1975, Die Kirchliche Dogmatik: Die Lehre von der Schöpfung, Dritte Auflage, Evangelischer Verlag Zollikon, Zürich.

Bauckham, R.J., 1982a, 'The Lord's Day', in D.A. Carson (ed.), From Sabbath to Lord's day: A biblical historical, and theological investigation, pp. 221-250, Wipf \& Stock, Eugene, OR

Bauckham, R.J., 1982b, 'Sabbath and Sunday in the Post-Apostolic church', in D.A. Carson (ed.), From Sabbath to Lord's Day: A biblical historical, and theological investigation, pp. 251-298, Wipf \& Stock, Eugene, OR.

Bird, F.B., 2009, Colossians \& Philemon: A new covenant commentary, Lutterworth Press, Cambridge, United Kingdom.

Carson, D.A. (ed.), 1999, From Sabbath to Lord's Day: A biblical, historical, and theological investigation, Wipf \& Stock, Eugene, OR. 
Cogliati, C., 2010, 'Background to volume', in D.B. Burrel, C. Cogliati, J.M. Soskice \& W.R. Stoeger (eds.), Creation and the God of Abraham, pp. 1-10, Cambridge University Press, Cambridge, United Kingdom.

De Lacey, D.R., 1982. 'The Sabbath/Sunday question and the Law in Pauline Corpus', in D.A. Carson (ed.), From Sabbath to Lord's Day: A biblical historical, and theological investigation, Wipf \& Stock, Eugene, OR.

Edwards, D., 2010, How God acts, creation, redemption and special divine action, Fortress, Minneapolis, MN.

Eichrodt, W., 1959, Theology of the Old Testament, vol. 1, SCM, London.

Fergusson, D., 2010, 'Creation', in J. Webster, K. Tanner \& I. Torrance (eds.), The Oxford handbook of systematic theology, pp. 72-90, Oxford University Press, Oxford, United Kingdom.

Groenewald, E.P., 1973, Die Evangelie van Lukas, N.G. Kerk-Uitgewers, Kaapstad.

Heschel, A.J., 1951, The Sabbath, its meaning for modern man, Noonday Press, Union Square West, New York.

Heyns, J.A., 1978, Dogmatiek, N.G. Kerkboekhandel, Pretoria.

Jaspers, K., 1969, Philosophy, vol. 1, The University of Chicago Press, Chicago, IL.

Jones, C.R., 2006, James K. Humpphrey and the Sabbath-Day-Advetists, University Press of Mississippi, Jackson, MS.

Kent, K.W., 2009, Rest, living in Sabbath simplicity, Zondervan, Grand Rapids, MI.

Kessler, V., 2012, 'The Sabbath as a remedy for human restlessness', In die Skriflig/In Luce Verbi 46(2), Art. \#61, 8 pages. https://doi.org/10.4102/ids.v46i2.61
Lowery, R.H., 2000, Sabbath and Jubilee, Chalice Press, St. Louis, MO.

McDowell, J. \& McDowell, S., 2013, The Bible handbook of difficult verses, Harvest House Publishers, Eugene, OR.

Möller, F.P., 1997, The wonder of creation and the enigma of spiritual beings, Van Schaik, Pretoria. (Words of Light and Life, vol. 5).

Möller, F.P., 1998, The wonderful Christ and the meaning of humanness, Van Schaik, Pretoria. (Words of Light and Life, vol. 2).

Moltmann, J., 1985, God in creation, SCM, Loondon, Great Britten. (The Gifford lectures 1984-1985).

Packer, J.I., 2007, Keeping the 10 Commandments, Crossway Books, Wheaton, IL.

Page, T.E. (ed.), 1965, The Apostolic Fathers, with an English translation by Kirsopp Lake, Harvard University Press, Massachusetts.

Rabbati, P., 1968, Discourses for feasts, fasts, and special Sabbaths, Trans. from Hebrew by W.G. Braude, Freie Universität Berlin, Yale University Press, New Haven, Connecticut.

Ringwald, C.D., 2007, A day apart: How Jews, Christians, and Muslims find faith, freedom, and joy on the Sabbath, Oxford University Press, Oxford.

Ryken, P.G., 2003, Written in stone: The ten commandments and today's moral crisis, Crossway Books, Wheaton, IL.

Schenck, R.L., 1999, The ten words that will change a nation, Albury Publishing, Tulsa, Oklahoma.

Schlessinger, L. \& Vogel, R.S., 1998, The ten commandments: The significance of God's Laws in every day, Perfectbound Publishers, Los Angeles, CA. 